\title{
Social Mapping and Development of Village Community Potentials
}

\author{
Social Mapping in Labuhan Village Community, Sepulu District, Bangkalan Madura
}

\author{
Pambudi Handoyo* \\ Department of Sociology, Faculty of \\ Social Sciences and Law, \\ Universitas Negeri Surabaya, \\ Surabaya 60231, Indonesia \\ pambudihandoyo@unesa.ac.id \\ M. Mudzakkir \\ Department of Sociology, Faculty of \\ Social Sciences and Law, \\ Universitas Negeri Surabaya, \\ Surabaya 60231, Indonesia \\ mudzakkir@unesa.ac.id
}

\author{
Arief Sudrajat \\ Department of Sociology, Faculty of \\ Social Sciences and Law. \\ Universitas Negeri Surabaya, \\ Surabaya 60231, Indonesia \\ ariefsudrajat@unesa.ac.id
}

\author{
Ardhie Raditya \\ Department of Sociology, Faculty of \\ Social Sciences and Law, \\ Universitas Negeri Surabaya, \\ Surabaya 60231, Indonesia \\ ardhieraditya@unesa.ac.id
}

\begin{abstract}
Social mapping is carried out to understand the social conditions of the local community. Social mapping in order to plan community empowerment models. Social mapping to provide a comprehensive picture of the mapped locations, including actors who play a role in the process of social relations, social networks, the strengths and interests of each actor in community life, especially in improving the living conditions of the community, existing social problems and including the existence of vulnerable groups, as well as the potential available, both natural, human, financial, and infrastructure as well as social capital. Social mapping is used as the basis for planning a model for community empowerment.
\end{abstract}

Keywords: social mapping, development, community potential

\section{INTRODUCTION}

Social mapping is an activity carried out to understand the social conditions of local communities. This activity is important to do because every community has different social conditions which will cause people to have different problems and needs. Social mapping, in addition to knowing the basic needs of the community, potential resources and social capital of the community, is also carried out to identify stakeholders in relation to the existence and activities of actors in the program, identify the root of the problems felt by the community in improving their welfare and analyze potential conflicts in the community.

As stated in the Green Proper Indicator Book of the Ministry of Environment, concerning the Aspects of Community Development in the Regulation of the Minister of Environment of the Republic of Indonesia Number 6 of 2013 concerning Proper, [1] that Social Mapping provides a comprehensive overview of the mapped locations, including actors play a role in the process of social relations, social networks, the strengths and interests of each actor in people's lives, especially in improving the living conditions of the community, existing social problems including the existence of vulnerable groups, as well as the potential available, both natural, human, financial, and infrastructure as well as social capital

\section{METHOD}

This research is a descriptive study because it describes the social mapping data of village communities that carry out the CSR program. Social mapping was carried out in Labuhan village, Sepulu District, Bangkalan, Madura, which is a Ring-1 area, which is a geographic area that is potentially affected by company operations with a radius of approximately $0-5 \mathrm{~km}$. Data collection through observation, village profile data collection, and Focus Group Discussion (FGD) with actors regarding interests, types and roles, social position, social networks, social problems, and village potential and development [1].

\section{RESUlts AND Discussion}

\section{A. Map of Actor Networks in Programs that are already running}

In the mainland area of Labuhan Village, there are no large companies that are present and carry out and mobilize local economic activities, but in the ocean area there is an economic activity of the large company Pertamina. The existence of Pertamina has had a positive impact on the people of Labuhan Village, one of which is improving the conditions of the Labuhan Village beach. Besides that, with the existence of Corporate Social Responsibility (CSR) funds, more or less villages also benefit, namely their attention to their existence as communities in the affected areas. Pertamina company CSR funding assistance which has been running in a sustainable manner. 
Pertamina's CSR programs as well as non-CSR programs from the government and local universities implemented in Labuhan Village, to date have not only led to one-time programs but have led to sustainable development and empowerment of rural communities. The disbursement of both CSR and non-CSR programs from the government for this village also depends on the network of village actors in designing and implementing this program. There are several village officials related to the implementation of CSR programs and existing government programs, here is a map of the actor's network, social position and their role in the ongoing CSR program:

Table 3. 1. Map of Actor Networks in ongoing CSR Programs

\begin{tabular}{|l|l|}
\hline $\begin{array}{l}\text { Village head } \\
\text { Posisi Sosial }\end{array}$ & \multicolumn{1}{|c|}{ Role in CSR Programs } \\
\hline Village head & $\begin{array}{l}\text { The legitimacy of the } \\
\text { proposed CSR program }\end{array}$ \\
\hline village secretary & $\begin{array}{l}\text { Implementing CSR program } \\
\text { administration }\end{array}$ \\
\hline BPD (Village Legislature) & $\begin{array}{l}\text { Supervisor of CSR program } \\
\text { implementation }\end{array}$ \\
\hline
\end{tabular}

Source: processed from primary data

\section{B. Map of Actors, Networks \& Social Mapping of Villages}

Labuhan Village is a village area that is still thick with coastal culture. The map of actor network patterns in this village is first, a network of strong people such as the Village Head or Klebun. Klebun's position in the community in the Sepulu district is a network of strong people. They have experiences as people who live in harsh environments. As a strong person, the gardeners have the power to decide and succeed the various activities that will be carried out in the village. Second, is a religious group. As a religious community, the position of religious groups is very important in this village. Its existence is highly respected in everyday life as a reference for various things. The position as a religious figure in society is very strong. Informally the community is used as a role model referred to to solve various village problems and become a unifying symbol for the Labuhan Village community in general. Third, is the organizational group, namely the Village Secretary, the position of the village secretary has a strong role in carrying out various matters related to village administration. He is always in touch with all Labuhan Village residents. The head of Gapoktan is an actor who often initiates new ideas in the village, such as cultivating cypress shrimp, as well as acting as a mediator between outsiders and insiders. Furthermore, the head of the fishermen group, who fosters the local fishing community, cooperates with outsiders and distributes the aid received to other fishermen. Finally, the head of the BPD, who has the power to oversee the implementation of regulations and all programs in the village. The fourth is an educated group in the health sector, namely the village midwife. Village midwives are often the first referral when health problems occur. He often provides medication, health services to rural communities and also provides heath information in the form of counseling.
Table 3. 2 Map of Actors Network in Labuhan Village

\begin{tabular}{|l|l|l|}
\hline \multicolumn{1}{|c|}{$\begin{array}{c}\text { Social } \\
\text { Position }\end{array}$} & Influence & \multicolumn{1}{|c|}{ Interest } \\
\hline Village head & Strong. & $\begin{array}{l}\text { Legitimacy of all } \\
\text { village activities }\end{array}$ \\
\hline $\begin{array}{l}\text { village } \\
\text { secretary }\end{array}$ & Strong. & $\begin{array}{l}\text { Perform } \\
\text { administrative } \\
\text { functions }\end{array}$ \\
\hline $\begin{array}{l}\text { Gapoktan } \\
\text { fishing }\end{array}$ & Strong. & $\begin{array}{l}\text { Mediator between } \\
\text { rural parties and } \\
\text { construction groups }\end{array}$ \\
\hline $\begin{array}{l}\text { Chairman of } \\
\text { group }\end{array}$ & Strong. & $\begin{array}{l}\text { Build a group of } \\
\text { fishermen }\end{array}$ \\
\hline $\begin{array}{l}\text { Religious } \\
\text { leaders }\end{array}$ & Strong. & $\begin{array}{l}\text { A role model for } \\
\text { society }\end{array}$ \\
\hline $\begin{array}{l}\text { Village } \\
\text { elders }\end{array}$ & Strong. & $\begin{array}{l}\text { Provide solutions to } \\
\text { village problems }\end{array}$ \\
\hline $\begin{array}{l}\text { Midwife } \\
\text { Head of BPD }\end{array}$ & Strong. & $\begin{array}{l}\text { Supervision of the } \\
\text { implementation of } \\
\text { village programs }\end{array}$ \\
\hline $\begin{array}{l}\text { head } \\
\text { dusun }\end{array}$ & Moderate & Information spreader \\
\hline
\end{tabular}

Source: processed from primary data

\section{Network Analysis}

In development, there are stakeholders and actors who play a role in it [2]. If the two of them can work together and synergize in planning, implementing and evaluating development programs, especially in Labuhan Village, the impact will further encourage the expected rate of change. Each stakeholder and actor has interests, strengths and social positions in society. Among the actors involved in development in Labuhan Village, there are different roles and contributions because each actor has different interests and powers in influencing the community. Therefore, each actor has a different contribution in influencing the development process. [3] The size of the power an actor has will determine whether the actor is in a position of domination or subordination. The position of the actor shows the magnitude and nature of the interests the actor has.

In society, there can be an actor who actually has a large enough interest and willingness to contribute to improving people's lives, but in reality his contribution is not optimal because it is not supported by adequate strength. On the other hand, in society there are actors who have great power both in the joint decision-making process and the ability to influence other citizens but these actors have a low interest in their contribution to the development process in the community, and even have the potential to become resistant [2]. 
The mapping of the strengths and interests of the actors of Labuhan Village is outlined in the following scheme:

\section{Scheme 3. 3 Mapping the strengths and interests of the Labuhan Village Actors}

\begin{tabular}{|c|c|c|c|}
\hline \multirow{3}{*}{ ¿ } & $\frac{\vec{E}}{20}$ & $\begin{array}{l}\text { Village elders, } \\
\text { religious } \\
\text { leaders }\end{array}$ & $\begin{array}{l}\text { Head of village, } \\
\text { village secretary, } \\
\text { Gapoktan, head of } \\
\text { fishermen group, } \\
\text { chairman of BPD }\end{array}$ \\
\hline & \multirow{2}{*}{ ف) } & $\begin{array}{l}\text { Village } \\
\text { midwife }\end{array}$ & Head of Dusun \\
\hline & & Low & Hight \\
\hline \multicolumn{4}{|c|}{ Interest } \\
\hline
\end{tabular}

Source: processed from primary data

The scheme contains four variations, the first variation is occupied by actors with high power and low importance. The first variation in the above scheme is occupied by religious leaders and village elders. The two actors have great power in the daily life of the people of Labuhan Village. This is due to the strong belief of the Madurese community to respect figures who have a big role in scientific development and life oriented towards Islam. However, its contribution to the development process in the community tends to be low because it is only oriented towards the development of a religious community.

In the second variation, it is occupied by actors with high power and high interests such as the Head of Labuhan Village, the Village Secretary, the Chairperson of Gapoktan, the head of the fishing group, and the chairman of the BPD. These actors have great power in the joint decision-making process and the ability to influence other residents, and have a high interest in contributing to the development process in the community, because every time there is a meeting or forum that discusses village problems, the five people are in position His presence is always needed, especially in decision making and contribution of thoughts to the Labuhan Village development program.

The third variation is actually occupied by actors with low power and low interests. The researcher included one of the Labuhan Village actors such as the Village Midwife. In this third variation, in general, many actors can be included because of their low strength and contribution to development. It can even be said that these actors had no influence at all on the Labuhan Village policy making process.

The fourth variation is occupied by actors with low power and high interests, namely occupied by the hamlet head. These actors have a high interest, especially in their contribution to fight for the interests of the whole society. On the other hand, its power is low because its legitimacy only includes residents in the local hamlet and does not cover all interest groups in Labuhan Village.

\section{Forum / Media Used for Discussion of Public Problems}

The patterns of the existence of the forum as a forum for community communication in Labuhan Village can be divided into, first, religiously oriented organizational patterns such as yasinan and tahlil. This forum is held once a week, namely yasinan and tahlil. This activity is carried out by moving from one place to another or in a village mosque.

Second, forums with nuances of livelihood, such as the existence of the Gapoktan forum specifically for residents whose eyes are as farmers, breeder forums for those who raise livestock and Fishermen's Groups for residents who work as fishermen. The Gapoktan meeting, breeder forum and fishermen group were held incidentally. They haven't had a fixed schedule in a year. They tend to hold meetings when one member of the community gets a problem that requires a joint solution.

The third forum is a public forum, this forum has very open membership. All residents will usually be invited to take part in the activities at this event, although sometimes it is done in a representative manner considering the very limited meeting places. For example, the village meeting forum, the Mangrove group forum. In the village forum, the implementation of the meeting is incidental. They do not have a fixed agenda and are more likely to meet if a problem arises in the village. Unlike the Mangrove Group forum, they hold a meeting every month.

And the fourth is a forum with health nuances. This forum takes the form of posyandu for toddlers and the elderly. The nature of the membership is very open to residents who have children under five and who are elderly. The schedule of meetings is usually once a month. In addition to implementing health programs, meetings at the posyandu forum, health education is often carried out for the community.

Table 3.4 Forum / Media Used for Discussion of Public Problems

\begin{tabular}{|l|l|l|}
\hline \multicolumn{1}{|c|}{ Forum } & Membership & \multicolumn{1}{c|}{ Meeting } \\
\hline $\begin{array}{l}\text { Village } \\
\text { meeting } \\
\text { forum }\end{array}$ & open & incidental \\
\hline Gapoktan & $\begin{array}{l}\text { Especially for } \\
\text { farmers }\end{array}$ & incidental \\
\hline $\begin{array}{l}\text { Fishermen } \\
\text { group }\end{array}$ & Fishermen & incidental \\
\hline $\begin{array}{l}\text { Breeder } \\
\text { group }\end{array}$ & breeder & incidental \\
\hline Religion: & $\begin{array}{l}\text { all local } \\
\text { Muslims }\end{array}$ & Once a week \\
\hline
\end{tabular}




\begin{tabular}{|l|l|l|}
\hline $\begin{array}{l}\text { Yasin and } \\
\text { tahlil }\end{array}$ & \\
\hline $\begin{array}{l}\text { Posyandu for } \\
\text { toddlers }\end{array}$ & $\begin{array}{l}\text { Families with } \\
\text { toddlers }\end{array}$ & Once a month \\
\hline $\begin{array}{l}\text { Posyandu for } \\
\text { the elderly }\end{array}$ & $\begin{array}{l}\text { Open to the } \\
\text { elderly }\end{array}$ & Once a month \\
\hline $\begin{array}{l}\text { Mangrove } \\
\text { group }\end{array}$ & open & Once a month \\
\hline
\end{tabular}

Source: processed from primary data

\section{E. Problem of Vulnerable Groups}

The vulnerable groups in Labuhan Village can be categorized as the first being vulnerable groups related to disabilities. In Labuhan Village, there are three residents as people with disabilities. So far, there are no groups or policies that are pro or concerned about their existence, let alone empowering them. So far, the existing programs tend to be for normal people only.

The second is vulnerable groups that refer to their livelihoods, such as groups of fishermen, ranchers and farmers. For fishermen groups, the absence of fishery product processing technology means that the selling price of their products is highly dependent on the market. They do not have more bargaining power, so they tend to rush to sell all their catch. If it is too late, the fish will quickly rot and the cost for preserving using ice is very large, not according to the selling price. The price obtained in the market is also very volatile, there are times when they are profitable, but they often get lost. For motorized boat owners, it is like they only get money as a substitute for fuel which can be used to go to sea the next day.

Farmers Group, tend to have problems related to the absence of water sources that meet their needs. The agricultural pattern in Labuhan Village tends to be very dependent on water sources that come from rain. Therefore, farmers in Labuhan Village can only plant once a year, while the remaining time is spent by doing activities outside the village such as carpentry or others. Likewise farmer groups, breeders in Labuhan Village are dominated by chicken. However, limited knowledge causes the death rate of chickens to be very high. The need for livestock instructors is highly anticipated. They need information on how to raise good, profitable and safe medicinal uses. They tend to get information from the experiences of less credible people.

The third vulnerable group is the poor. The number of poor people in Labuhan Village is quite a lot. They are very dependent on marine products, but their skills and production tools are very limited. This causes the production results to be inadequate to lead a better life. Their income is only enough to survive.

The fourth vulnerable group is the youth group. The youth group in Labuhan Village lacks good skills provision. They only get religious knowledge. The lack of facilities in Labuhan Village to develop the creativity of teenagers causes them to tend to be a less productive group. They are less empowered to become skilled workers.
Table 3.5 Problem Vulnerable Groups and Needs for Intervention

\begin{tabular}{|c|c|c|}
\hline Group & Problem & Needs \\
\hline $\begin{array}{l}\text { Persons with } \\
\text { disabilities }\end{array}$ & $\begin{array}{l}\text { disability (mental } \\
\text { disability) }\end{array}$ & $\begin{array}{l}\text { psychiatrist and, } \\
\text { material help }\end{array}$ \\
\hline Farmer & $\begin{array}{l}\text { water sources are } \\
\text { not sufficient to } \\
\text { irrigate rice fields }\end{array}$ & $\begin{array}{l}\text { water pump as } \\
\text { well as make good } \\
\text { irrigation }\end{array}$ \\
\hline Nelayan & $\begin{array}{l}\text { Facilities and } \\
\text { infrastructure for } \\
\text { processing catch } \\
\text { for commercial } \\
\text { purposes }\end{array}$ & $\begin{array}{l}\text { Training for } \\
\text { processing marine } \\
\text { products }\end{array}$ \\
\hline Breeder & $\begin{array}{l}\text { The mortality rate } \\
\text { for chickens is } \\
\text { still a lot }\end{array}$ & Need counseling \\
\hline $\begin{array}{l}\text { Mangrove } \\
\text { group }\end{array}$ & $\begin{array}{l}\text { The cultivated } \\
\text { mangroves have } \\
\text { not yet been } \\
\text { processed }\end{array}$ & $\begin{array}{l}\text { There needs to be } \\
\text { expert personnel } \\
\text { to conduct } \\
\text { training. }\end{array}$ \\
\hline Poor Family & $\begin{array}{l}\text { Only rely on sea } \\
\text { products }\end{array}$ & $\begin{array}{l}\text { There is skills } \\
\text { training to utilize / } \\
\text { cultivate Natural } \\
\text { Resources }\end{array}$ \\
\hline Youth & $\begin{array}{l}\text { Lack of facilities } \\
\text { to develop } \\
\text { creativity }\end{array}$ & $\begin{array}{lr}\text { facilities } & \text { to } \\
\text { support } & \text { and } \\
\text { develop } & \text { youth } \\
\text { creativity } & \end{array}$ \\
\hline
\end{tabular}

Source: processed from primary data

\section{F Village Potential}

The potential in Labuhan Village is quite large. The first is related to natural potential. In Labuhan Village, the huge natural potential is in the form of marine products, namely fish and crabs, which are very abundant. Then the livestock products in the form of cows, goats and chickens have been cultivated by the local community for a long time. Furthermore, the existence of very abundant mangrove forests almost along the village coastline is a great potential for the village. The last one is the success of the local community in developing a typical tree of Madura Island, namely the massive shrimp cypress and the existence of a "magic island" which is now the icon of Labuhan Village.

Second, related to the potential of human resources [4]. In Labuhan village, there are people who are very skilled in fishing, canoe makers, net makers, farmers, breeders and crab entrepreneurs. Their existence requires a touch of the most recent knowledge and adequate means of production so that their level of productivity can increase and become better.

Third, related to the potential for tangible facilities and infrastructure in Labuhan Village such as village sports fields, places of worship, village roads that have been paved with good asphalt and some are paved, then educational facilities such as PAUD, SDN and madrasah, health facilities such as posyandu, polindes. , as well as the street lights that are quite bright, and the last one is the sea defenses, and the pancung. Tangkis Laut as a barrier for waves and the behead as a marker for coral reefs. Both of 
these facilities are very important for fishermen's productivity so that they can work properly and safely without worrying about the risk of damage to production equipment such as leakage of boats or canoes.

Fourth, is the potential for social capital in the form of relationships with outside companies with regard to labor recruitment, networks with outside entrepreneurs related to the absorption of production products in the form of fish and crabs, then the existence of various existing interest groups such as Gapoktan, Farmers' Forum, Fishermen and Breeders and the level very good community religiosity.

The last potential is the existence of ancient tombs which are often referred to as "bujuk".

\section{G. Development of the Potential of Labuhan Village}

Referring to the potential that exists in Labuhan Village, the opportunities for development and empowerment in the future will be very large, such as natural potential, firstly related to existing mangroves and pine trees that can be developed and reproduced with better technology such as tissue culture, for that we need experts who can assist and process the existing mangrove tree production. secondly, the development of crops and peanuts to be more productive and not dependent on rain and water pumps that are wasteful of energy, thirdly development and improvement of the quality of fish ponds and crab fishing, fourth development and improvement of the quality of livestock businesses that meet health standards and finally increasing public understanding regarding waste processing.

Regarding the potential of human resources, it is necessary to develop in the future, first in the form of training, counseling as a creative solution in developing local experts in the fields of livestock, fisheries, agriculture, health and education. The existence of programs like the one above is expected so that people can be independent in developing themselves and their products. They no longer always depend on nature but have developed it, such as crab, prawn cypress and mangroves. That way, they can develop better without having to depend on nature every year. The second is in the form of capital which will help them overcome liquidity difficulties in purchasing capital goods that support their productivity. Capital can be in the form of savings and loan cooperatives with soft interest.

The number of agencies that are vertical, autonomous in nature does not exist in Labuhan Village, as well as the existence of State-Owned Enterprises and Village-Owned Enterprises. This condition causes the people of Labuhan Village to require initiation related to capacity building of village communities. The development of the capacity of the village community is very important in the midst of the presence of coastal tourism destinations that suddenly appear there, namely the existence of a "magic island" as an added value for the development of Labuhan Village in terms of village income. Magic islands are new land mounds that rise from the ocean floor to the surface. The new land area allows people to reach and enjoy a small island with coral reefs. This phenomenon has invited various layers of society from outside the village to visit both ordinary people and officials.

The development of the potential for infrastructure is in the form of improving educational facilities such as fulfilling the most essential facilities such as libraries, language labs and computers. The importance of the existence of better maritime infrastructure such as breakwaters in increasing the productivity of fishermen. The existence of Tangkis Laut is deemed ineffective in withstanding quite harsh waves, especially in certain months. In addition, for the sake of effectiveness of village activities, it is necessary to build a separate village hall. Do not depend on housing facilities from the village head. With the existence of the village hall itself, whoever becomes the village head can carry out activities without disturbing the personal life of the village head.

The potential for social capital in the future can be in the form of cooperation in community empowerment according to the existing potential, then the need to develop more intensive cooperation between members of the community of different professions. The last one is the development of another potential in the form of developing tourism assets. The existence of two important sites such as the ancient tomb and the "magic island" in Labuhan Village, if properly arranged, will make Labuhan Village a tourist destination

Table 3.6 potential development of Labuhan village

\begin{tabular}{|c|c|c|}
\hline Potency & $\begin{array}{l}\text { Present } \\
\text { Condition }\end{array}$ & $\begin{array}{l}\text { Develpoment } \\
\text { Opportunities }\end{array}$ \\
\hline $\begin{array}{l}\text { Natural } \\
\text { Potential }\end{array}$ & $\begin{array}{l}\text { Dry land, Little } \\
\text { seawater, Many } \\
\text { dead chickens }\end{array}$ & $\begin{array}{l}\text {. lanted with } \\
\text { palawija } \\
\text { peanuts, } \\
\text { Developing a pond } \\
\text { business, there } \\
\text { needs to be } \\
\text { counseling about } \\
\text { proper breeding }\end{array}$ \\
\hline $\begin{array}{l}\text { human } \\
\text { resources } \\
\text { potential }\end{array}$ & $\begin{array}{ll}\text { Lack } & \text { of } \\
\text { manpower } & \text { to } \\
\text { manage } & \\
\text { mangroves } & \end{array}$ & $\begin{array}{l}\text { there is a need for } \\
\text { members } \\
\text { empower } \\
\text { mangroves for the } \\
\text { common good }\end{array}$ \\
\hline $\begin{array}{l}\text { Finantial } \\
\text { Potency }\end{array}$ & $\begin{array}{l}\text { Village funds, } \\
\text { company funds } \\
\text { around, and } \\
\text { private donors }\end{array}$ & $\begin{array}{l}\text { Financial } \\
\text { management needs } \\
\text { to be adjusted } \\
\text { according to needs. }\end{array}$ \\
\hline $\begin{array}{l}\text { Infrastru } \\
\text { cture } \\
\text { Potency }\end{array}$ & $\begin{array}{l}\text { The madrasah } \\
\text { has not been } \\
\text { renovated for a } \\
\text { long time and it } \\
\text { looks like } \\
\text { something is } \\
\text { damaged } \\
\text { The trash can is } \\
\text { still minimal } \\
\text { sea fence is } \\
\text { under repair }\end{array}$ & $\begin{array}{l}\text { There needs to be } \\
\text { renovation to the } \\
\text { madrasa } \\
\text { it is necessary to } \\
\text { procure a trash can } \\
\text { It is necessary to } \\
\text { have a wave } \\
\text { breaker, because } \\
\text { blocking the sea is } \\
\text { not effective enough }\end{array}$ \\
\hline $\begin{array}{l}\text { Social } \\
\text { Capital } \\
\text { Poyency }\end{array}$ & $\begin{array}{l}\text { Cooperation } \\
\text { with local } \\
\text { companies is } \\
\text { going well } \\
\text { Gapoktan } \\
\text { Fishermen } \\
\text { group } \\
\text { mangrove group }\end{array}$ & $\begin{array}{l}\text { Cooperation to } \\
\text { empower } \\
\text { communities } \\
\text { according to } \\
\text { existing potential. } \\
\text { Fostering } \\
\text { cooperation } \\
\text { between (farmers, }\end{array}$ \\
\hline
\end{tabular}




\begin{tabular}{|l|l|l|}
\hline & Ranch group & $\begin{array}{l}\text { fishermen, } \\
\text { breeders) and other } \\
\text { parties related to the } \\
\text { development of the } \\
\text { group. }\end{array}$ \\
\hline $\begin{array}{l}\text { Other } \\
\text { Potency }\end{array}$ & $\begin{array}{l}\text { There is an } \\
\text { ancient tomb } \\
\text { which it necessary to } \\
\text { considered to be } \\
\text { the first to } \\
\text { occupy the } \\
\text { village, as well } \\
\text { as a magical } \\
\text { island }\end{array}$ & $\begin{array}{l}\text { improve procurement the of } \\
\text { facilities in the } \\
\text { the port village. (ex; } \\
\text { adequate trash bins) }\end{array}$ \\
\hline
\end{tabular}

Source: processed from primary data

\section{CONCLUSIONS}

Social mapping to understand the social conditions of local communities. Social mapping is used to plan community empowerment models. Social mapping can provide a comprehensive picture not only of the mapped locations, but includes actors who play a role in the process of social relations, social networks, the strengths and interests of each actor in community life, especially in improving the living conditions of the community. Social mapping also identifies existing social problems, including the existence of vulnerable groups, and maps the potential that exists in society, both natural, human, financial, and infrastructure as well as social capital. And then social mapping is used as the basis for planning a community empowerment model.

\section{ACKNOWLEDGMENT}

Acknowledgments are conveyed to the Directorate of Research and Community Service in Higher Education, through the Advanced Applied Research Scheme, 2020.

\section{REFERENCES}

[1] Bahruddin, Krisdyatmiko, Danang Arif Darmawan dan Soetomo, Indikator Proper Hijau: Aspek pengembangan Masyarakat (Community Development). Deputi Pengendalian dan Pencemaran Kementerian Lingkungan Hidup Republik Indonesia., No Title. 2013

[2] E. Sukmayeti, "Pemetaan Sosial terhadap Sumberdaya dan Aksesibilitas Nelayan dalam Kebijakan Pembangunan Wisata Pesisir," Society, vol. 7, no. 2, pp. 125-145, 2019, doi: 10.33019/society.v7i2.101.

[3] S. K. Moerad, W. Windiani, S. Mukhtar, and M. Nurif, "Pemetaan Sosial Budaya Masyarakat Desa Sumber Agung Kecamatan Pesanggaran Kabupaten Banyuwangi," J. Sos. Hum., vol. 7, no. 1, pp. 61-74, 2014, doi: 10.12962/j24433527.v7i1.596.

[4] Y. Wibisono, Membedah Konsep dan Aplikasi CSR. Gresik: Fascho Publishing. 2007. 